\title{
The Power of Narrative
}

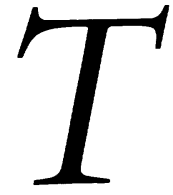
he connection may not seem obvious, but written sources are an integral part of the archaeological record. In addition to being the cornerstone of any hermeneutical process, they are an important tool in helping us understand the mute archaeological remains. Written sources are critical in the study of Hittite Anatolia not only because they provide straightforward historical accounts of the Hittites but also because they illustrate the literary values and abstract thought processes that pervaded every aspect of Hittite life. The study of Hittite literature illustrates that archaeology and philology are indeed complementary disciplines and that their relationship must be carefully cultivated if we are to unravel the puzzles of the past. In the following pages I will discuss the underlying elements of the Hittite literary tradition and present several passages from various texts to show both the development of that tradition and the power of its prose.

\section{The Hittite Archives}

The obvious place to begin any discussion of Hittite literature is the archives at the Hittite capital of Hattuša near the modern-day district town of Boğazköy/ Boğazkale (see Akurgal 1978: 300-01). Although little has been written about the archives (Laroche 1949; Otten 1955, 1984,1986 ), it is from these written sources that we get our initial impressions of the role literature played in the Hittite state.

We must be cautious, however, when speaking of the Hittite archives. The word archive connotes a building or structure and implies the notion of a library or the like.
This is certainly not the correct impression to give. The Hittites built no institution that approached the functioning of a library. We cannot even be sure that the structures in which tablets have been found were actually intended to be tablet houses, or archives, in the physical sense of the word. Thus, in this article, the word archive is used to denote the collections of tablets that have been found throughout the Hittite capital. Relatively few tablets have been found in the provinces (compare Özgüç 1978: 57-58).

The tablets unearthed at Hattuša were scattered in buildings throughout the site. In the Lower City, tablets were found in several rooms of Temple 1, the great temple of the Weather-God (Otten 1955: 72; Bittel 1970: 13-14; Naumann 1971: 430; Akurgal 1978: 302). On the acropolis, site of the great fortress of Büyükkale, tablets were found in three structures-Buildings $\mathrm{A}, \mathrm{E}$, and $\mathrm{K}$ (Bittel 1970: 84-85, 163). Many tablets were also found in the so-called House on the Slope (Schirmer 1969: 20), perhaps the scribal school (Macqueen 1986: 116, note 71). More tablets are being unearthed in the Upper City (Otten 1984: 50, 1987: 21; Neve 1985: 334, 344, 1987a: 405, 1987b: 311 ), among them a sensational tablet made of bronze that was found underneath the paving stones alongside the inner city walls near Yerkap1 (Neve 1987a: 405; Otten 1988, 1989).

We can say very little about the physical structures in which the Hittites kept and stored their tablets. At Hattuša tablets were found collected in temples, houses, magazines, and perhaps special tablet houses. Others were discovered in widely scattered areas and dumps. There does not seem to have been a

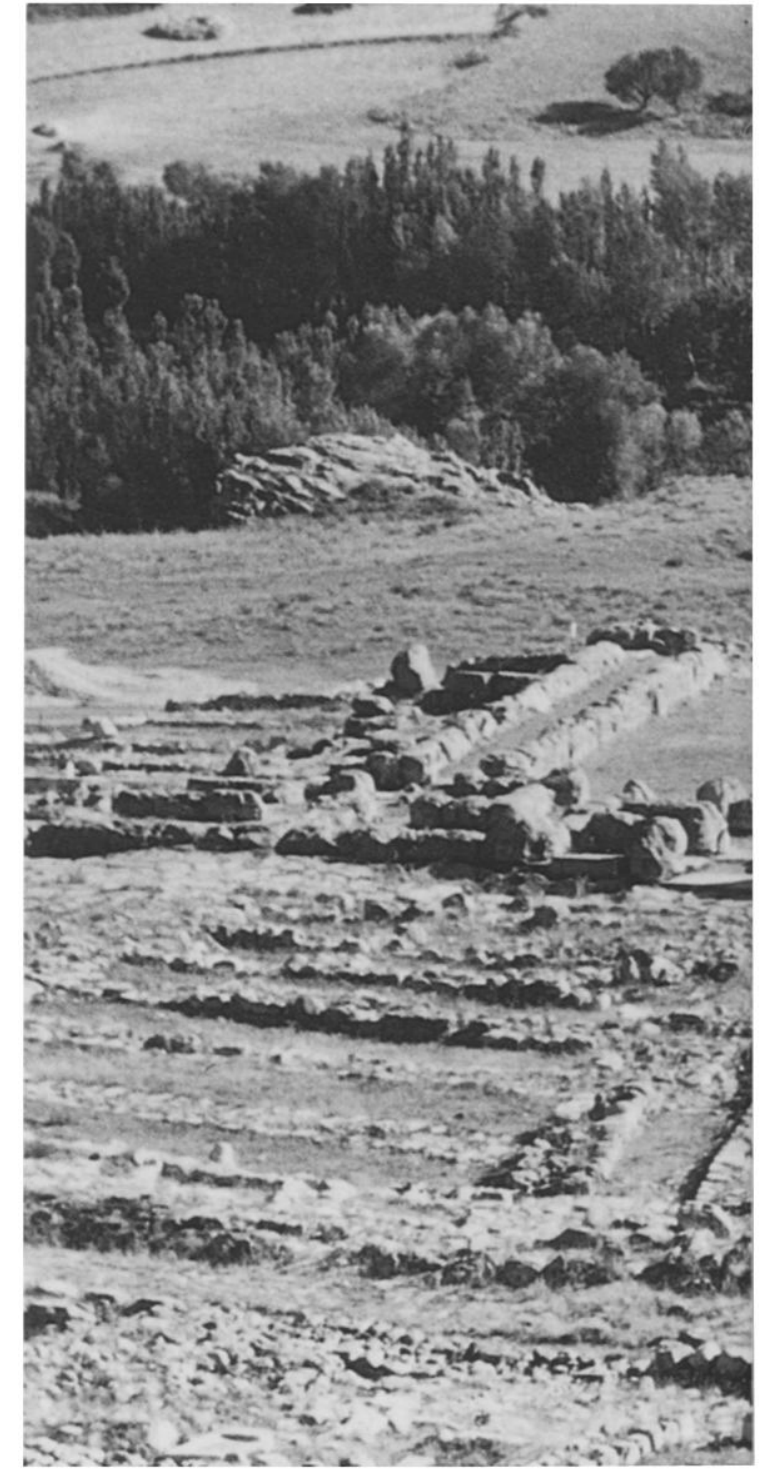

particular system of distribution. (An overview of find spots according to CTH numbers can be found in Cornil 1987.)

We have determined how the tablets were organized from the structures in which they were housed as well as from the so-called shelf lists (Laroche 1971: 154). It is presumed that these shelf lists were placed as indices in front of the tablets for quick reference. Some of the 


\section{in Hittite Literature}

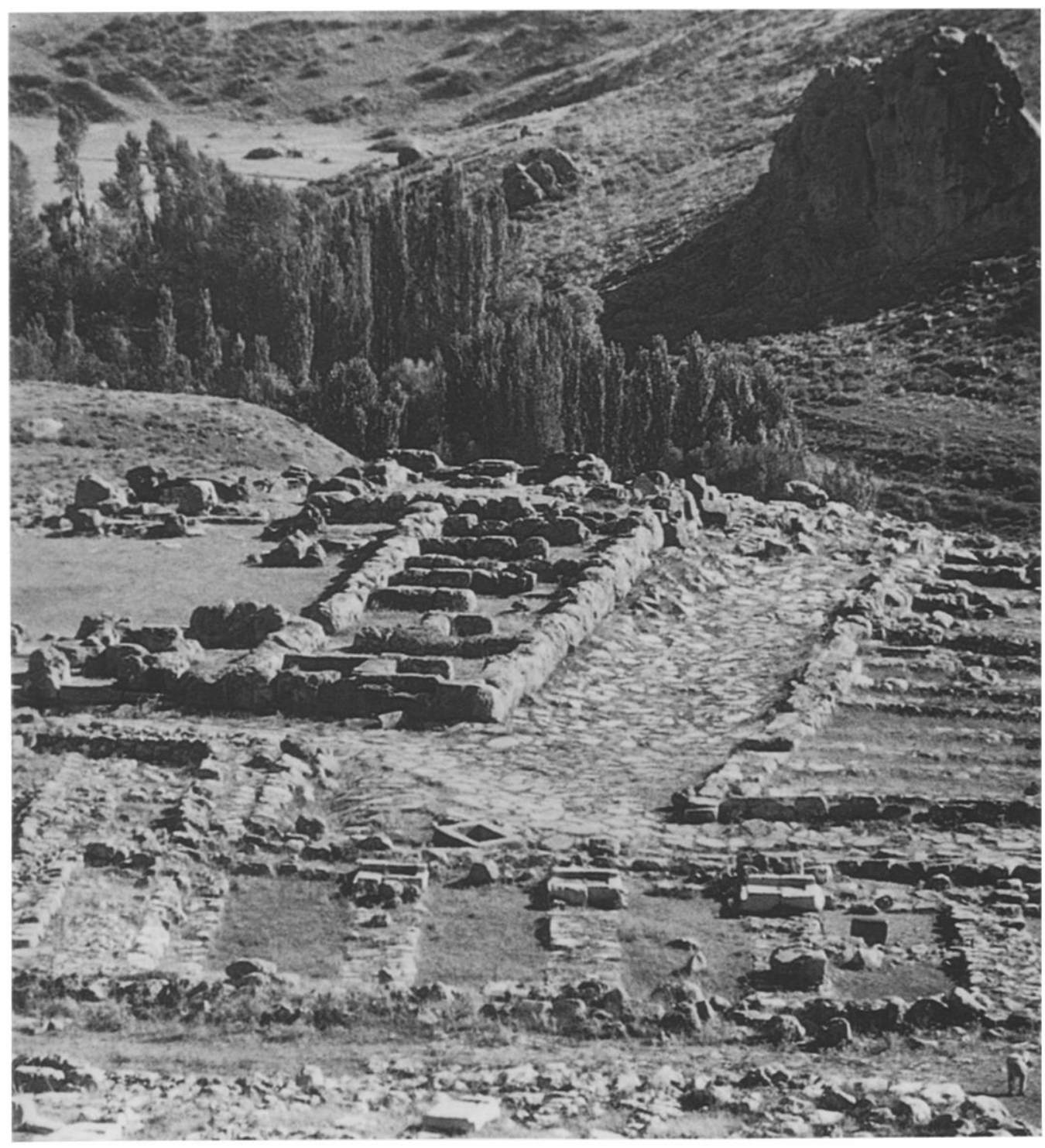

structures, especially Buildings A and $\mathrm{K}$ in Büyükkale, had rooms with parallel rows of stone pillars that might have supported wooden racks or shelves for the tablets rather than a second story (Neve 1982: 106, 108, and plans 41,45$)$. At one time the tablets may have resided in a few specially established tablet houses, but it is possible that some tablets were moved to secondary locations during the rebuilding and reorgani- zation of the city in the final phase of the empire (Laroche 1975: 57; Bittel 1970: 85). This may be illustrated by the discovery of Old and Middle Hittite land grants dating to the sixteenth and fifteenth centuries B.C.E. in the newly excavated temples in the Upper City (Otten 1987), which date to the thirteenth century B.C.E.

Other types of tablets have also been found in the Upper City. In

\section{by Abmet Ünal}

Tablets have been found scattered throughout the Hittite capital of Hattuša, including the great temple of the Weather-God, shown here, located in the Lower City. The entire complex, including the central courtyard and surrounding storerooms, measures about 525 feet at its longest point. Visible in the rear of the photo, attached to the central courtyard, is an annex with ritual chamber (adyton). Photo by Ronald L. Gorny.

addition to the land grants, HurroHittite bilingual literary texts, rituals, letters, and divination texts have been found as well as the previously mentioned bronze tablet that details the treaty between Hattušili III and his nephew, Kurunta, the vassal king of Tarhuntašša (Otten in Neve 1987a: 405; Otten 1988, 1989).

\section{Hittite Scribes and the Pursuit of Writing}

It appears that writing was brought to Anatolia by the Old Assyrian merchants who established trading centers in important cities across the central plateau during the early part of the second millennium B.C.E. The Assyrians brought their own system of writing, called Old Assyrian script, the use of which is thought to have died out with the demise of the kärum system around 1750 B.C.E. The Old Babylonian script, on which Hittite was based, is generally thought to have been first used somewhat later by Old Babylonian scribes who are said to have been brought to Hatti during the campaigns of the first Hittite kings into northern Syria (Beckman 1983: 100, note 17).

It has always been thought that the use of these two scripts was mutually exclusive because they pertained to different eras that were several hundred years apart. Such a 
Most of the best-preserved clay tablets in the Hittite archives were found in this structure, Building $A$ in Büyükkale, the fortress located southeast of the great temple at Hattuša. About 105 feet long, Building A consisted of four storerooms and a long lateral corridor. Pictured in the storerooms are the remaining rectangular limestone bases that once supported parallel rows of pillars, which might have supported wooden racks or shelves for the tablets rather than a second story of the building. Stone bases were not found in the long, outer room to the east of the storerooms. Courtesy of Peter Neve and the German Archaeological Institute.

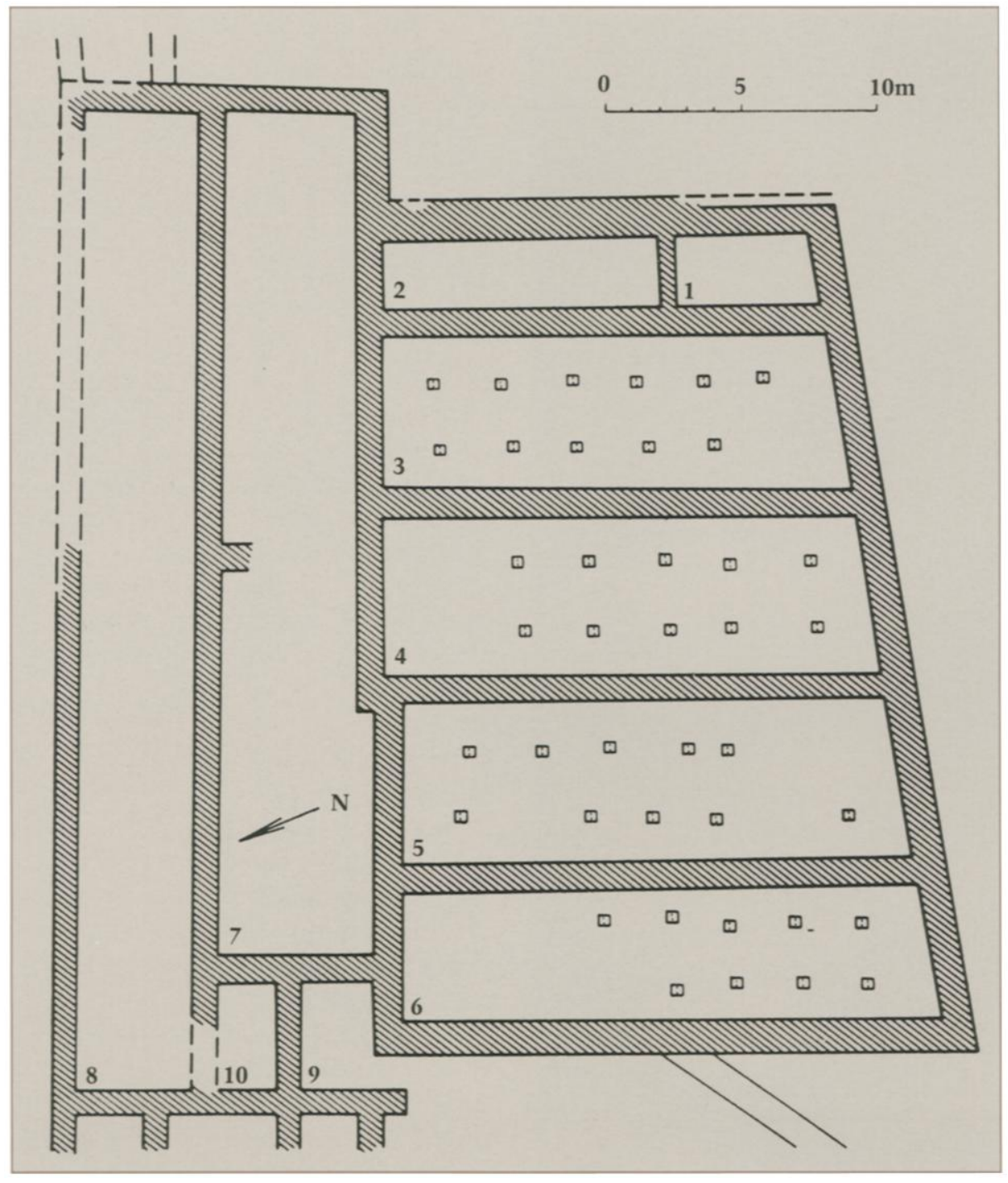

scenario would leave a literary gap of between one and two centuries in central Anatolia. In the view of Hans Güterbock (1983a: 24-25), it is possible that the princes of the early city-states employed Assyrian-trained scribes to document their dealings with the Assyrian merchants and Babylonian- or Syrian-trained scribes for documents written in Hittite. Examples to support this idea, however, have not turned up in any excavation.
The Anitta Text (CTH 1), one of the oldest Hittite texts, may be the translation of a text originally written in Old Assyrian, then the only literary language in central Anatolia. Some scholars suggest, however, that ties generally found in a translation (Neu 1974: 132; see overview in Ünal 1983b) and that it may have been originally written in Hittite by Anitta's Babylonian-trained scribes (Güterbock 1983a: 24-25). As the the piece displays none of the quali- bullae from Acemhöyük suggest (N. Özgüç 1986: 48), non-Assyrian scribes could have been plying their trade in the central Anatolian Highlands long before the alleged importation of the Old Babylonian script during the reign of Hattušili I. This would suggest that the origins of Hittite literature could go somewhat farther back than originally thought, possibly pulling the date of Anitta's reign closer to the supposed origins of Hittite history. This theory remains vague, however, and still offers no clue as to Anitta's ethnic origin.

Contacts between central Anatolia and northern Syria are known to have already taken place in the last half of the third millennium B.C.E. (T. Özgüç 1986: 31). The city of Kaneš was probably a principal partner in this trade, so it is not unreasonable to think that the cradle of Anatolian literary development could be found there. The fact that the language of the Hittites is called nešumnili- "in the language of Neša"-lends credibility to this suggestion. Could it be that the Hittites were already developing the rudiments of a written language during the period of the Assyrian merchants? There is no evidence to substantiate this suggestion at present, but excavations in the non-Assyrian parts of Kültepe may eventually bear it out.

The heyday of the Babylonian scribes in Anatolia seems not to have occurred until after the period of the Assyrian trade settlements, however. There is well-documented evidence for such a presence in the late fourteenth and the thirteenth centuries B.C.E., but the tradition probably dates even earlier since a Babylonian scribal school had apparently been established at Hattuša by the late fif- 


\section{The heyday of the Babylonian scribes seems to have occurred after the Assyrian settlements.}

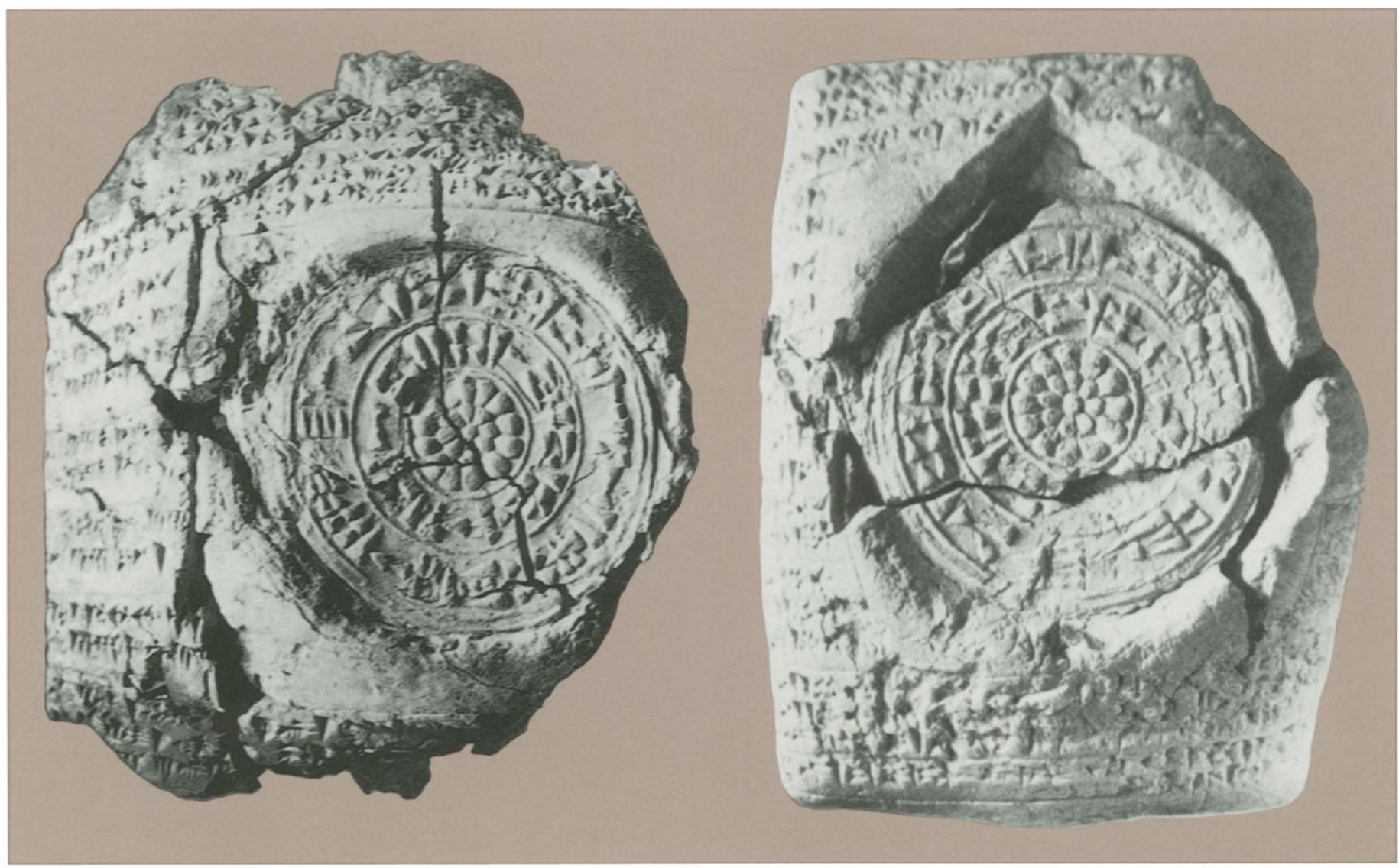

Tablets may have once resided in specially established tablet houses, but it is possible that some might have been moved to secondary locations during the rebuilding and reorganization of Hattuša in the final phase of the empire. The discovery of land grants dating to the pre-Empire period, like the two pictured here, may illustrate this possibility. The cuneiform seal in the center of the clay tablet to the left identifies it as belonging to Zidanta, an Old Kingdom ruler, whereas the land grant to the right is identified by its center cuneiform seal as belonging to Arnuwanda I, a Middle Kingdom ruler. Both tablets were discovered at the site of ancient Hattuša. Photos courtesy of Peter Neve and the German Archaeological Institute.

teenth or early fourteenth century (Beckman 1983: 106). It is important to add that the Hurrian scribal tradition was having an immense impact at the time (Mascheroni 1984), and many of the Mesopotamian influences noted in later Hattuša may have originally been transmitted through this medium.

One type of Hittite scribe was called the scribe of the wooden tablets, which may be a reference to scribes who wrote on folding wooden tablets constructed with a recessed area to hold a wax substance on which daily notices and receipts were written. No traces of this highly perishable material have been found preserved in Anatolia, but one example was recently excavated about 150 feet underwater at the site of an ancient shipwreck off the coast of Turkey at Ulu Burun near Kaș. The tablet has been called the world's oldest known "book" (Bass 1987: 730). Another writing system that was practiced by the Hittites is the so-called Luwian hieroglyphs. Scribes who used wooden tablets might have used this style of writing instead of cuneiform for their day-to-day records. Although Luwian hieroglyphs seem to have been popular in the middle of the second millennium B.C.E., some efforts have been made to push the origins of this writing system back as far as the third millennium or the first half of the second millennium, but without convincing proof (overview by Alp 1968: 281).

\section{The Earliest Literary Sources}

Hittite literature appeared on the scene in an already well-established style soon after the foundation of the Old Kingdom and the adoption of the Old Babylonian writing sys- 
tem. It seems clear that some sort of developmental stage must have transpired prior to its full-blown appearance as the literary medium in central Anatolia. Whether this medium was the result of an earlier development in the so-called Dark Age, of Syro-Babylonian involvement during the reign of Hattušili I, or even of Hurrian scribes remains debatable, but future research will certainly reveal an enormous Hurrian impact on Hittite literacy. A great deal of new evidence will eventually come from Hattuša as well as southeastern Anatolian and north Syrian sites, and these texts may enlighten us about the origins of the Hittite script. The fact remains, however, that we now see no obvious preliminary or experimental stage of development. This is the case in many Hittite genres, but especially in the literature that displays a complex narration of events and procedures, examples of which are found in the earliest written sources.

The Political Testament of Hattušili I (CTH 6), for instance, gives a verbatim record of a speech given by the king to an assembled court for the purpose of dismissing his son from succession to the throne. Especially poignant are the following passages:

"I, the king, called him my son, embraced him, exalted him, and cared for him continually. But he showed himself a youth not fit to be seen: He shed no tears, he showed no pity, he was cold and heartless."

The force of the narrative leads one to anticipate the conclusion:

"Enough! He is my son no more!" (Gurney 1981).

Throughout the text there is no trace of scribal alteration; it seems

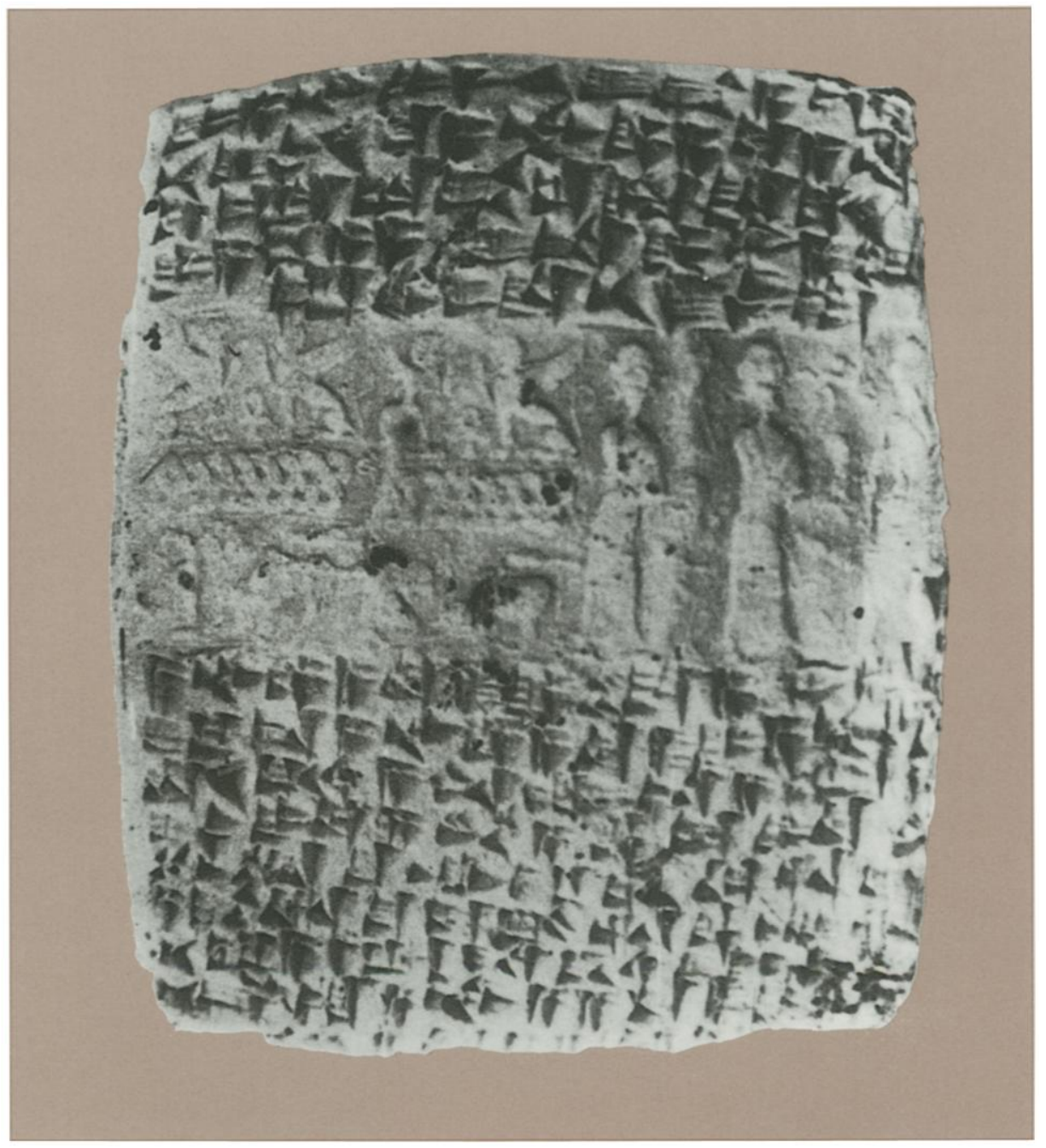

This twice-impressed envelope of an Old Assyrian tablet was found in Level $1 b$ at Kültepe, site of ancient Kaneš. In the scene, worshippers are guided by a God-King. Above the wide guilloche are two sphinxes with an ankh sign between them; below them is a bull scratching the ground and an eagle seated upright. Most tablets from Kültepe $1 b$ have this type of impression. Photo courtesy of Tahsin Özgüç.

to have been recorded directly from the king's mouth.

The so-called Palace Chronicle (CTH 8), a series of anecdotal admonitions, illustrates a distinct genre that seems to have emerged during the Old Hittite kingdom. This collection, which has been preserved on many tablets dating to different periods of Hittite history, is not simply part of an oral tradition. As reflections of real events, these stories played a propagandistic role in the Hittite subjugation of the Anatolian population, revealing a way of life that was vital and dynamic on the one hand and harsh and brutal on the other. The persons mentioned in these stories seem to be partly historical, partly fictional. The collection can be considered a literary achievement because of its unique style of narration. The language is cryptic, but the author's effort is keenly felt as he tries to impress his message with words calculated to instill fear in wrongdoers. Taken from different aspects of daily life, the anecdotes seem to encourage loyalty and good conduct by illustrating that evil will be punished and that good will be rewarded:

(Once there was) a high functionary named Pappa. He was found 

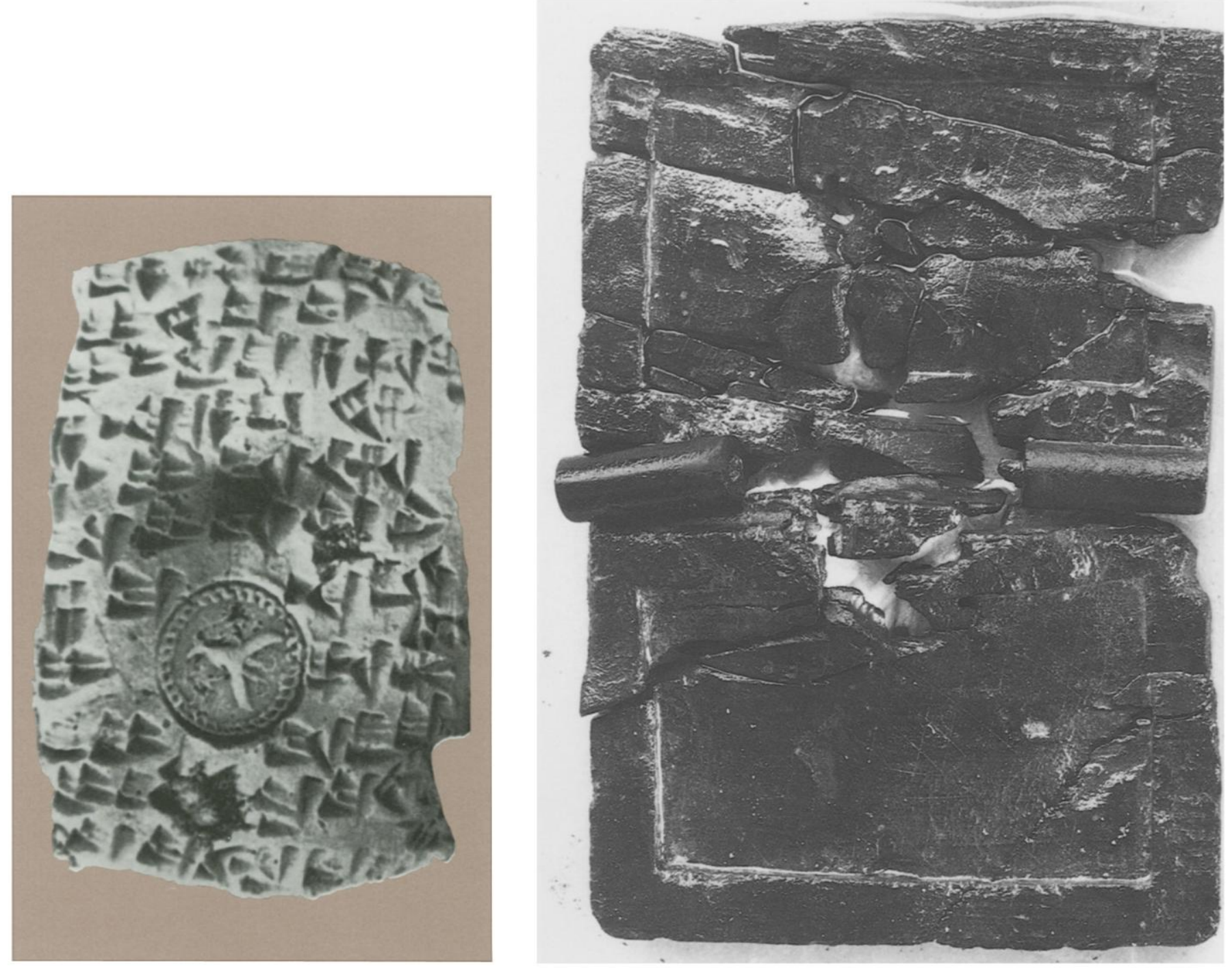

Left: Also found at Level $1 \mathrm{~b}$ at Kültepe (ancient Kaneš) is this Old Assyrian tablet with a seal impression of a double-headed eagle within a guilloche border with a star on each side between the tail and wings. Photo courtesy of Tahsin Ozgüç. Right: Some Hittite scribes wrote on folding wooden tablets constructed with a recessed area to hold a wax substance on which daily notices and receipts were written. No traces of this highly perishable material have been found in Anatolia, but this wooden tablet, shown vertically, was recently found about 150 feet underwater in an ancient shipwreck excavated off the coast of Turkey at Ulu Burun, near Kaş. The tablet, or diptych, has been called the world's oldest known "book." Photo courtesy of George F. Bass and the Institute of Nautical Archaeology, Texas A \& M University.

to be fraudulently distributing army-bread and marnuwan-drink (among the people) in the city of [Tameni]nka. (The authorities) [squashed] the bread and smeared the upper part of his body (with it). (Further) they poured out salt into [marnuwan-]cup and made him drink it. They broke the cup on his head. (Because) he (also) was distributing in Hattuša (illegally) walhi-drink to the soldiers, they took a šaggavessel and broke it (too) on his head (KBo 3.34 I 5-g). Other Old Hittite authors also used the power of narrative to make their points. In contrast to later literature with its emphasis on divine inspiration and empowerment, this power was often rooted in the omnipotence and wisdom of the king. Thus we should not be surprised to find examples where the king is presented as making wise pronouncements that imply great royal power. In the Benediction for Labarna, for example, the king commands:
"Let the whole country be inclined toward Hattuša behind his back. The king himself is vigorous. He is (also) able to keep the country vigorous. The king's house is (full) of rejoicing and grandchildren. It is set on (solid) ground" (KUB 36.110 rev. $\left.9^{\prime}-16^{\prime}\right)$.

Similarly there is a royal admonition to:

"give him (that is, a sick person) bread and water. If somebody is struck by heat, let him be taken 
The longest hieroglyphic monument dating to the Hittite Empire period is this weathered, 11-line inscription located on a sloping hill at Nişantepe in the Upper City at Hattuša. About 28 feet long, the inscription apparently dates to the reign of Suppiluliuma I. Photo by Ronald L. Gorny.

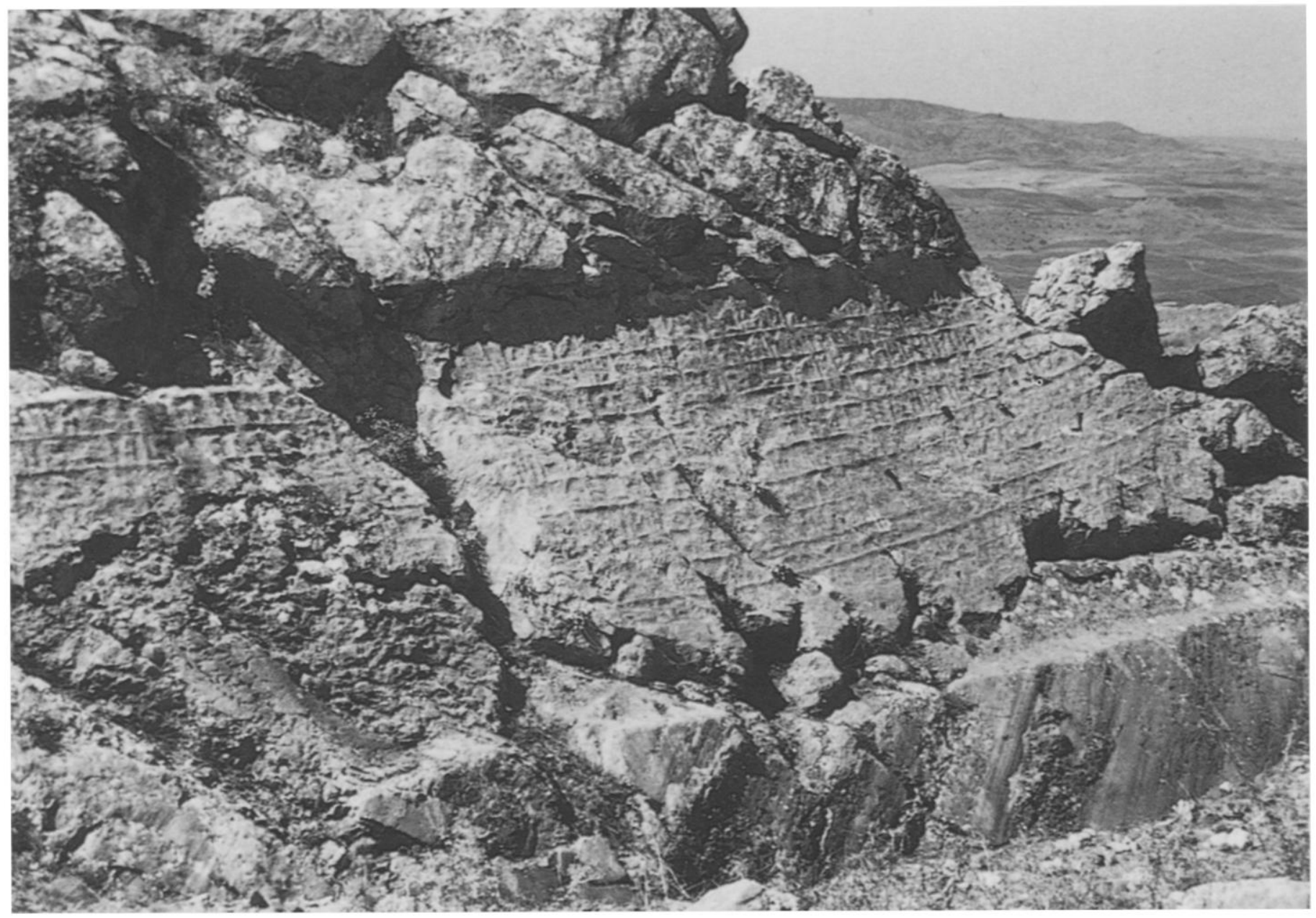

to a cool place; if the cold chills somebody, let him be taken to a warm place. Let the king's subjects not be oppressed!" (Archi 1979: 37).

These passages have been compared with a story detailed in a HurroHittite bilingual from Hattuša in which the Storm-God Tešub has gotten into debt (KBo $32.15 \mathrm{i}$-ii; Neu 1988a: 16, 1988b, 1988c, 1988d). While Tešub tries to extricate himself from the situation, other gods assist him as a token of solidarity, supplying him with silver, gold, food, garments, and refined oil, all of which he needs. Such acts symbolize liber- ation or releasing (para tarnumar), which is the main theme of Old Hittite stories. In light of Hittite interaction with nearby Hurrian principalities, we should ask to what extent these genres are to be considered strictly Hittite since there is strong evidence that many typically Hittite ideas were actually borrowed from the Hurrians and the Babylonians.

One of our first examples of Hattušili I's involvement in military affairs is the Akkadian text describing the Siege of Uršu, an important Hurrian city in southeastern Anatolia (Beckman, forthcoming). The text describes the toils and frustrations felt by the king during this bitter siege in which Hittite forces were evidently inferior to the Hurrians in both manpower and equipment. In addition, the Hittite military commanders are described (in a surprisingly frank manner) as weak, slack, and ineffective. Thus it is left to the tireless and courageous efforts of the Hittite king to overcome the Hurrian forces who are propping up the city of Uršu. The king's frustration is evident in his animated response to finding out that the battering ram has been broken:

The king waxed wrath and his face was grim (as he yelled), 


\section{Old Kingdom literature tried to involve the reader so that the conclusion was seen as inevitable.}

"They constantly bring me evil tidings; may the Weather-God carry you away in flood! Be not idle! Make a battering ram in the Hurrian manner and let it be brought into place. Make a mountain (that is, siege machine) and let it (also) be set in its place. in its place. Hew a great battering ram from the mountains of Haššu and let it be brought into place. Begin to heap up earth. When you have finished let every one take post" (KBo 1.10 obv.! $13^{\prime}-17$ ', translated by Gurney 1981: 180-81).

It is almost as if the king were saying, "Do I have to tell you how to do everything?"

These descriptions are as much a literary device as a historical narration of the facts. They set the stage for a statement of the king's wise and courageous decisions, the purpose of which is to emphasize his role and lead the reader to the obvious conclusion that without the king all would be lost. Unfortunately, the end of the story is missing (but compare the Annals of Hattušili I in KBo 10.1 i 15 and following).

The Old Hittite culmination of this literary pattern is found in the Telipinu Edict (CTH 19). The powerful narration of the tragic events leading up to this decree presents the reader with what amounts to an apologetic discourse. In contrast to the passionate pronouncement of Hattušili I, this decree is formulated in a very unemotional way and with an objectivity peculiar to legal texts. It is, however, a very idealized account of the remote past presented in a schematized form that leaves one with a strong impression of the force of law. Like the Political Testament of Hattušili I, the Telipinu
Edict has a sense of growing anticipation and fulfilled expectation, which inevitably arise with the final stipulations of the decree. Telipinu thus succeeds in presenting his reforms, not as mere stipulations but as a well-structured literary composition (Sturtevant and Bechtel 1935: 175; Hardy 1941: 190; Liverani 1977: 105; Hoffmann 1984: 13).

\section{The Development of an Emphasis on the Divine}

The literature of the Old Hittite Kingdom presents us with a basic outline in which the Hittites couched much of their later literature. Basic to this style is an attempt to involve the reader in the events being described so that the conclusion is seen as inevitable. The outcome is determined by the wise actions of the king on one hand and the leading heroes on the other.

Other genres borrowed heavily from this style, for example, the annalistic tradition. Although the most fully developed example of this very Hittite genre dates to the reign of Muršili II, forerunners can be found in texts dating to both the Old and the Early New Kingdoms, such as the annals of Hattušili I, Tudhaliya III, and Arnuwanda I. These texts are not merely records of events; they are realistic narratives of campaign strategy that attempt to involve the reader in the development of various ideas to their expected conclusions (Cancik 1976). Preceding events and simultaneous actions and circumstances are described perfectly, and the underlying reasons for the decisions are aptly given. In the Annals of Muršili II, for example, we read:

"Because the whole enemy population fled to Mount Arinnanda) I, my majesty, went (also) to Mount Arinnanda. Now this Mount Arinnanda is very steep and extends into the sea (that is, it is on a peninsula). It is also very high, difficult of access, rocky, and impossible for chariots to drive up.... Since it was impossible to drive with chariots, I, my majesty, went guiding my army in front on foot and clambered up Mount Arinnanda on foot" (Goetze 1933: 54).

The facts are clearly organized, but the presentation is far from objective. The description is constructed to make the reader sympathize with the king and his difficulties at the same time commending his courage and wisdom in making tactical and strategic decisions. It is also notable for the gratitude that the king accords his patron deity whom he believes supports him throughout his lifetime. In fact, this deity may have been thought to be the sole reader of the text. That is, the king presents an account of his reign to his divine overlord for whom he governs the Hatti lands as a proxy. This may be the precursor of depicting kingship in terms related not so much to wisdom and courage as to divine providence and empowerment. It foreshadows the "orientalizing" of Hittite kingship, which came to fruition under the last kings of the empire.

The best example of this new trend can be seen in the Apology of Hattušili III (CTH 81), a highly sophisticated and unique composition whose purpose was to justify his seizing the throne. Hattušili tells about his childhood, describing how he was dedicated to the goddess Ištar and how he, always an innocent babe, was surrounded by jealous enemies. Except for the deity, almost 


\section{Hurro-Hittite bilinguals are rare examples of what in Mesopotamia was called wisdom literature.}

everybody is presented as envious of this child prodigy. The story goes on to tell how Ištar enabled Hattušili to prevail against the continuous evil deeds and plots concocted by these enemies. This document, which has few parallels in pre-Classical antiquity, suggests a highly developed political consciousness that relies on reasoned argumentation to make a point (Goetze 1925; Sturtevant and Bechtel 1935: 64; Wolf 1967; Ünal 1974: 29; Otten 1981). As with its predecessors, this trend is dependent on the reader's involvement: Its success relies on the power of the narrative to lead the reader subconsciously to a desired conclusion, in this case, that Hattušili had done no wrong but sat on the throne only as a result of his natural right of succession and divine selection.

\section{Narration in Legal Texts}

Narration was just as powerful in the legal sphere, especially in putting forward specific cases. Hittite legal process used oratory and complex reasoning in the pleading of cases. Among the official documents we have found are depositions, that is, testimonies from the proceedings of legal inquests. There are, for example, speeches made in self-defense by men accused of having stolen or lost items for which they had been given responsibility. These testimonies, which are preserved in the records of Hittite court clerks, deserve special treatment here because they are the literary forerunners of pre-Socratic apologetics that use oratory as a means of self-defense.

The best example of these testimonies is the case of Ištar-ziti, who was apparently indicted for a scandalous affair of unknown nature. In his defense Ištar-ziti uses metaphors such as "I am cast down like a reed on the dark earth" and "as a living person I am dead in the eyes of my siblings." A few more of his well-turned phrases help illustrate this style:

"Have I not always been a (true) servant of that deity? . . Once when I was taken ill, I prayed to the gods, saying: 'Do not you see, o gods, who has ruined me like this (as I am right now)?' Instead you have weighed on me! (Is it because) you do not want to harm (literally defeat) the king, his majesty? If you always appreciate the absolute truth, why is it that matters are still concealed? ... When something evil happened to the royal heir in the city of Kummanna, Ali-Šarrumma revealed to me that they intended to kill me (because they thought I was guilty in that matter). (On my way to Mount Šahhupidda) the queen intended to have someone lie in ambush behind the road and kill me! ... (From my eyes) the tears flow [like water in the mountains]. These tears I will give to the priest of the Sun-God and he shall pour them out secretly for the Sun-God. . . . One day in the city of Sulama I was honoring the god Tarupšani. (A man by the name of) Muti walked in and started to gossip about my person. I seized him by the collar (and) brought him to [the sacred place]. I made him take an oath and warned him (at the same time), saying: '(Behold!) Whoever takes a (false) oath in the presence of this deity, he does not survive anymore!' " (KUB 54.1; my translation differs in many cases from that of Archi and Klengel 1985).
The Role of the Hurrians

The intermediary role of the Hurrians is one of the most important occurrences in Hittite history because it brought about the incorporation of Hurrian customs and beliefs into the indigenous Hittite culture.

Hurrians first appear in the historical texts as enemies of the Hittites. Convincing evidence is lacking, but direct influence may already have begun in the Old Kingdom. Visible influences are more readily observed from the Early Empire period under Tudhaliya III and Arnuwanda I. By the time of Hattušili III and his Hurrian wife Puduhepa, the Hurrian cultural invasion was well under way. From the Early Empire on the Hurrian influence began to be felt so strongly that some scholars believe the dynasty to be of Hurrian origin. Indeed much evidence points to this conclusion. A case in point is the large number of Hurrian texts or their translations found at Hattuša. These include the Kingship in Heaven story and the Song of Ullikummi. Of special interest are the newly discovered Hurro-Hittite bilinguals from the Upper City, which will certainly change our views of Hittite intellectual life during the last two centuries before the downfall of the empire. It would be appropriate, therefore, to take a closer look at the contents of these newly discovered texts, so far as details are yet available.

The Hurro-Hittite bilinguals (Otten 1986; Neu 1988a, 1988b, 1988 c) are rare examples of what in Mesopotamia was called wisdom literature in which good and bad, represented as humans, animals, and various objects, appear as active figures opposing each other. Animals and inanimate objects are depicted in the form of a clerihew as imbecilic 
beings, short of wit, and lacking the ability to reason. They can only use their instinct, whereas humans are endowed with wisdom and insight (Hittite, hattatar; Hurrian, madi-). A greedy deer, for example, is compared to an ambitious governor. The literary theme in these pieces is, again, liberation, release from evil (para tarnumar; Neu 1988a: 10), and perhaps the reestablishment of primary divine order on earth. Whether they played a part in magical rituals or festivals (perhaps not unlike Illuyanka in the purulli-festival) is not clear.

Both Hittite and Hurrian versions reveal meticulous efforts to structure the composition, which indicates that they are not mere scribal exercises but first-class literary exemplars. They are designated as "song, poetry" (SÌR), and both contain traces of well-organized verse, which can be observed in Hattic texts as well (KUB 38 p. ivf., "Gruppe II"; Haas and Thiel 1978: 66-90). Groups of stories all seem to have a single author, as the narrator introduces successive stories with the words, "I will put aside this story (literally, words) and will tell you another." This is important in regard to the individual authorship of literary works, although, unfortunately, in general the authors did not sign their names (see Güterbock 1978: 213). Evidently, as with the later Homeric epics, the literary devices used by these authors were not of their own invention but were taken from the vast resources of an evergrowing folklore tradition.

The following passage, in which an analogy is made between an ungrateful copper cup and a man's son, will illustrate this point:

(Once) a coppersmith cast a splendid cup. By casting it he gave it a (beautiful) shape. $\mathrm{He}$ embossed it with plates and engraved it. He made it brilliant in every detail. However, the simple (-minded) copper began to curse its creator, saying: "Whoever has cast me-; may his hand break, may the sinew of his right arm be paralyzed!" As the coppersmith heard this he was grieved in his heart. The coppersmith began to speak to himself: "I formed that copper (into a beautiful cup). Why does it (now) curse me?" The coppersmith uttered a curse over the cup: "May the Storm-God smite it, the cup, may he remove its plates. May the cup fall down the water drainage ditch, may (its) plates fall down into the river!"

The analogous story runs as follows:

(This time it is) not a cup, but a human. It is a son who after growing up became an adversary to his own father. He pays no attention to his father. As a result the paternal deities cursed him!

Perhaps also connected to Hurrian influence is the common motif of child exposure found in three texts from ancient Anatolia that tell the stories of children from humble beginnings who end up achieving astonishing power and success. These stories are the oldest examples of a motif that can be seen in such famous later examples as Sargon of Akkad, Moses, Romulus and Remus, and Darius. It seems that this literary motif found its way into Hittite Anatolia through Hurrian intermediaries. Its origin is probably to be found in the Hurrian regions of the upper Tigris and Euphrates rivers (Ünal 1985: 135).

One of the Hittite stories that falls into this category is the Queen of Kaneš (Neša)/Thirty Sons and Daughters/Zalpa Text (CTH 3; Otten 1973; see glossary listing). This text has been evaluated in terms of a preHittite matriarchal structure evident in the Hatto-Hittite world that completely rejected incest. Because of the role of the river and the dismissal of the male progeny, some laymen have connected this text to the legendary Amazons of Greek mythology who would meet men in the river valleys for orgiastic ceremonies. This view may not be as farfetched as it once seemed in light of festival text records that describe a northern Anatolian custom in which young girls were taken from their towns, stripped in the river valley, and evidently raped (unpublished text is discussed in Forlanini 1984: 256 and following). The story of the Queen of Kaneš may also indicate a process of political integration in central Anatolia, a suggestion that has recently led to the notion of a kind of amphictyonic league in the region (Dieterle 1987).

Perhaps the best example of the motif of child exposure is the story of Anum-Hirbe, a prince of the city of Mama who seems to have established a relatively large kingdom somewhere on the periphery of the realm of Kaneš. Anum-Hirbe's prominence gave rise to the story of a legendary birth and childhood: Apparently born out of wedlock, he was carried off by the people of Mama and probably thrown into a river. A shepherd or a sheep found him and carried him to a meadow where he was suckled by animals. The remainder of the story has been lost, but we can imagine the gist of it - Anum-Hirbe overcame all odds and returned to Mama as its king 


\section{Continued development of Hittite culture led to more complex ideas concerning the afterlife.}

(Ünal 1985: 132-35). Once again, the reader is captivated by the incredible events and can only conclude that it was divinely ordained that AnumHirbe rise to such heights.

\section{Literature as a Conveyor of Hittite Thought}

Contacts with the rest of the ancient Near East and the continued development of Hittite culture led to more complex ideas concerning the afterlife. A preoccupation with these ideas elicited deep feelings and intangible, abstract ideas; it also brought about the stoic recognition that "life is bound up with death, and death is bound up with life" (Goetze 1969b: 400). These feelings must have tested the capability of Hittite literature to convey complex ideas. Whereas the earlier literature used vivid accounts and tense narrative to convey its message, this later literature emphasized content over style, often attempting to give a theological reason for events and expressing a new understanding of the relationship between the king and the world. This emphasis, mirrored in the work of Hittite artists from the same period, expressed itself in an overall artistic style calculated to enhance the position of the king. We find something similar in the Hurro-Hittite bilinguals and their attempt to interpret wisdom as well as in the attempt to define a religious hierarchy in the Kingship in Heaven story (CTH 344). The fact that so much of this literature can be attributed to Hurrian influence suggests that this philosophical development occurred partly as a result of Anatolia's interaction with the more advanced civilizations to the southeast, that is, Mesopotamia.

\section{Conclusion}

During the thirteenth century в.C.E., Hattuša was an important crossroads and, consequently, was open to a variety of influences. In it resided an elite composed of aristocrats, bureaucrats, scribes, and artisans, many of whom represented different ethnic backgrounds. This complex demographic mix led to the development of new trends, concepts, and ideas. Simple literary forms no longer satisfied this urban caste. As a result, in this period there was an increasing influx of new literary materials from the south, materials that were more sophisticated and abstract in style. We can only speculate how far this development would have gone if the Hittites had not met an unfortunate end shortly after 1200 в.C.E.

\section{Bibliography}

Akurgal, E.

1978 Ancient Civilizations and Ruins of Turkey from Prehistoric Times until the End of the Roman Empire, translated by J. Whybrow and M. Emre. Istanbul: Haşet Kitabevi.

Akurgal E., and Hirmer, M.

1962 The Art of the Hittites. London: Thames and Hudson.

Alp, S.

1968 Zylinder-und Stempelsiegel aus Karahöyük bei Konya. Series: Türk Tarih Kurumu Yayinlarindan, Series V, Number 26. Ankara.

Archi, A.

1968 La storiografia ittita. Athenaeum 47: 7-20.

1979 L'humanité des hittites. Pp. 37-48 in Florilegium Anatolium: Mélanges offerts à Emmanuel Laroche. Paris.

Archi, A., and Klengel, $\mathrm{H}$.

1985 The Selbstrechtfertigung eines hethitischen Beamten. Archiv für Orientforschung 12: 52-64.

Bass, G. F.

1987 Oldest Known Shipwreck Reveals Splendors of the Bronze Age. NationBeckman, G. al Geographic 172(6): 693-732.

1982 The Anatolian Myth of Illuyanka.
Journal of the Ancient Near Eastern Society 14: 11-25.

1983 Mesopotamians and Mesopotamian Learning at Hattuša. Journal of Cuneiform Studies 35: 97-114.

1986 Proverbs and Proverbial Allusions in Hittite. Journal of Near Eastern Studies 45: 19-30.

forth- The Siege of Uršu Text (CTH 7) and coming Old Hittite Historiography. In Memorial Volume for Charles Carter, edited by Y. Arbeitman.

Bernabé, A.

1987 Textos literarios hetitas. Madrid: Alianza Editorial.

Bittel, K

1970 Hattusha: The Capital of the Hittites. New York: Oxford University Press.

Bryce, T. R

1982 The Major Historical Texts of Early Hittite History. Series: Historical and Social Documents of the Hittite World. Queensland: University of Queensland.

Cancik, C.

1976 Grundzüge der hethitischen und alttestamentlichen Geschichtsschrei-

Cornil, P. bung. Wiesbaden: Otto Harrassowitz.

1987 Textes de Boghazköy. Liste des lieux de trouvaille. Hethitica VII: 5-72.

Dieterle, R. L.

1987 The Thirty Brothers. Journal of Indo-European Studies 15: 169-214.

Edel, E.

1952 Die Rolle der Königinnen in der Ägyptisch-hethitischen Korrespondenz aus Boğazköy. Indogermanische Forschungen 60: 72-85.

1953 Weitere Briefe aus der Heiratskorrespondenz Ramses' II: KUB III 37 + KBo I 17 und KUB III 57. Pp. 31-63 in Geschichte und Altes Testament. Tübingen: J. C. B. Mohr (Paul Siebeck).

1976 Ägyptische Ärtze und ägyptische Medizin am hethitischen Königshof: Neue Funde von Keilschriftbriefen Ramses' II aus Boğazköy. Opladen: Westdeutscher Verlag.

Forlanini $\mathrm{M}$.

1984 Die "Götter von Zalpa." Hethitische Götter und Städte am Schwarzen Meer. Zeitschrift für Assyriologie und Vorderasiatische Archäologie 74: 245-66.

Friedrich F.

1926 Staatsverträge des Hatti-Reiches in hethitischer Sprache I. Series: Mitteilungen der VorderasiatischÄgyptischen Gesellschaft 31.1. Leipzig: J. C. Hinrichs.

1930 Staatsverträge des Hatti-Reiches in hethitischer Sprache II. Series: Mitteilungen der VorderasiatischÄgyptischen Gesellschaft 34.1. Leipzig: J. C. Hinrichs. 
Gaster, T. H.

1958 Thespis. Ritual, Myth and Drama in the Ancient Near East. New York: Schuman.

Glassner, J. J.

1985 Sargon "roi du combat." Revue d'Assyriologie et d'archéologie orientale 79: 115-26.

Goetze, A.

1925 Hattušiliš, der Bericht über seine Thronbesteigung nebst den Paralleltexten. Series: Mitteilungen der Vorderasiatisch-Ägyptischen Gesellschaft 38. Leipzig: J. C. Hinrichs.

1928 Madduwattas. Series: Mitteilungen der Vorderasiatisch-Ägyptischen Gesellschaft 32.1. Leipzig: J. C. Hinrichs.

1930 Die Pestgebete des Muršiliš. Kleinasiatische Forschungen 1: 161-251.

1933 Die Annalen des Muršilis. Series: Mitteilungen der VorderasiatischÄgyptischen Gesellschaft 38. Leipzig: J. C. Hinrichs.

1957 Kleinasien. 2. Auflage. Series: Handbuch der Orientalistik III.1.3.3.1. Munich: C. H. Beck.

1969a Hittite Myths, Epics and Legends. Pp. 120-26 in Ancient Near Eastern Texts Relating to the Old Testament third edition, edited by J. B. Pritchard. Princeton, NJ: Princeton University Press.

1969b Rituals, Incantations and Descriptions of Festivals. Pp. 393-400 in Ancient Near Eastern Texts Relating to the Old Testament, third edition, edited by J. B. Pritchard. Princeton, NJ: Princeton University Press.

Goetze, A., and Pedersen, $\mathrm{H}$.

1934 Muršilis Sprachlähmung. Series: Det Kgl. Danske Videnskabernes Selskab, Historisk-filologiske Meddehelser 21.2. Copenhagen.

Grottanelli, C.

1978 Observations sur l'histoire d'Appou. Revue Hittite et Asianique 36: 49-57.

Gurney, O. R.

1940 Hittite Prayers of Muršili II. Annals of Archaeology and Anthropology 27: 3-163.

1977 Some Aspects of Hittite Religion. Series: The Schweich Lectures 1976. Oxford: Oxford University Press.

1981 The Hittites. New York: Penguin Books.

Güterbock, H. G.

1938 Die historische Tradition und ihre literarische Gestaltung bei Babyloniern und Hethitern bis 1200 . Zeitschrift für Assyriologie, Neue Folge 10: 45-149.

1948 The Hittite Version of the Hurrian Kumarbi Myths: Oriental Forerunners of Hesiod. American Journal of Archaeology 52: 123-34.
1952 The Song of Ullikummi: Revised Text of the Hittite Version of a Hurrian Myth. New Haven, CT: American Schools of Oriental Research.

1954 The Hurrian Element in the Hittite Empire. Cahiers d'Histoire Mondiale (Journal of World History) II: 383-94.

1956 The Deeds of Šuppiluliuma as Told by His Son Muršilis II. Journal of Cuneiform Studies 10: 41-130.

1961 Hittite Mythology. Pp. 139-79 in Mythologies of the Ancient World, edited by S. N. Kramer. Garden City, NY: Doubleday.

1964 A View of Hittite Literature. Journal of the American Oriental Society 84: 107-15.

1969 Sargon, König der Schlacht. Mitteilungen der Deutschen Orientgesellschaft 101: 14-26.

1978 Hethitische Literatur. Pp. 211-53 in Neues Handbuch der Literaturwissenschaft, edited by W. Röllig.

1983a Hittite Historiography: A Survey. Pp. 21-35 in History, Historiography, and Interpretation, edited by $\mathrm{H}$. Tadmor and M. Weinfeld. Jerusalem: Magnes Press.

1983b A Hurro-Hittite Hymn to Ishtar. Journal of the American Oriental Society 103: 155-64.

1986 A Religious Text from Maşat. Jahrbuch fur Kleinasiatische Forschungen 10: 205-14.

Güterbock, H. G., and Civil, M., editors

1985 Erim-huš Boghazköy. Series: Materials for the Sumerian Lexicon XVII: 97-128. Rome: Pontificum Institutum Biblicum.

Haas, V.

1980 Betrachtungen zum ursprünglichen Schauplatz der Mythen vom Gott Kumarbi. Studi Micenei ed EgeoAnatolici 22: 97-105.

Haas, V., and Thiel, H. J.

1978 Die Beschwörungsrituale der Allaiturah(h)i und verwandte Texte. Series: Alter Orient und Altes Testament 31. Neukirchen: Neukirchener Verlag.

Hardy, R. S.

1941 The Old Hittite Kingdom: A Political History. American Journal of Semitic Languages and Literature 58: 177-216.

Hoffmann, I.

1984 Der Erlaß Telipinus. Series: Texte der Hethiter 11. Heidelberg: Carl Winter.

Hoffner, H. A.

1968 A Hittite Text in Epic Style about Merchants. Journal of Cuneiform Studies 22: 34-45.

1975 Hittite Mythological Texts: A Survey. Pp. 136-45 in Unity and Diversity, edited by H. Goedicke and J. J. Roberts. Baltimore: Johns Hopkins Univer- sity Press.

1980 Histories and Historians of the Ancient Near East: The Hittites. Orientalia 49: 283-332.

1981 The Hurrian Story of the Sungod, the Cow and the Fisherman. Pp. 18994 in Studies on the Civilization and Culture of Nuzi and the Hurrians in Honor of E. R. Lacheman, edited by M. A. Morrison and D. I. Owen.

1987 Hittite Religion. Pp. 408-14 in The Encyclopedia of Religion, edited by M. Eliade.

1988 The Song of Silver. A Member of the Kumarbi Cycle of "Songs." Pp. 143-65 in Documentum Asiae Minoris Antiquae: Festschrift für Heinrich Otten zum 75. Geburtstag.

Hrozný, B.

1929 L'Invasion des Indo-Européens en Asie Mineure verse 2000 av. J.-C. Archiv Orientální 1: 273-99.

Imparati, F., and Saporetti, C.

1965 L'Autobiografia di Hattušili I. Studi classici e orientali 14: 40-85.

Kammenhuber A.

1955 Die hethitische Geschichtsschrei bung. Saeculum 9: 135-55.

1967 Hethitische Gebete, Hethitische Geschichtsschreibung, Hethitische Gesetze, Hethitische Mythen, Hethitische Pferdetexte, Hethitische Rituale, Hurritische Mythen. Sp. 1731-52, 2267-74 in Kindlers Literaturlexikon, volume 3 .

Kapelrud, A. S.

1959 The Interrelation between Religion and Magic in Hittite Religion. Numen 6: 32-50. (Reprinted on pp. 165-83 in God and His Friends in the Old Testament, 1979, Oslo: Universitets Forlaget|

Kempinski, A.

1983 Syrien und Palästina (Kanaan) in der letzten Phase der Mittelbronze IIBZeit (1650-1570). Series: Ägypten und Altes Testament 4: 14-53.

Kühne, C.

1978 Hittite Texts. Pp. 146-84 in Near Eastern Religious Texts Relating to the Old Testament, edited by $\mathrm{W}$. Beyerlin. Philadelphia: Westminster Press.

Laroche, E.

1949 La bibliothèque de Hattusa. Archiv Orientální 17: 7-23.

1969 Textes mythologiques hittite en transcription. Paris: Klincksieck.

1971 Catalogue des textes hittites. Paris: Éditions Klincksieck. (Supplement in Revue Hittite et Asianique 30: 94-133)

1975 Les écritures d'Asie Mineure: état des déchiffrements. Pp. 57-60 in Le Déchiffrement des écritures et des langues. 
1977 Littérature hittite; littérature hourrite et ourartéenne. Pp. 119-36 in Histoire des litteratures, Encyc. Pleiade, volume 2.

Lebrun, $\mathrm{R}$

1980 Hymnes et prières hittites. Series: Homo Religiosus 4. Louvain-la-neuve: Centre d'Histoire des Religions.

Liverani, $M$.

1977 Storiografia politica hittita-II Telipinu, ovvero: della solidarità. Oriens antiquus XVI: 105-31.

Macqueen, J. G.

1986 The Hittites and their Contemporaries in Asia Minor, revised and enlarged edition. London: Thames and Hudson.

Mascheroni, L. M.

1984 Scribi hurriti a Boğazköy: una verifica prosografica. Studi Micenei ed EgeoAnatolici 24: 151-73.

Melchert, H. C.

1986 Hittite uwaš and Congeners. Indogermanische Forschungen 91: 102-15.

Naumann, $\mathrm{R}$.

1971 Architektur Kleinasiens. Tübingen: Ernst Wasmuth.

Neu, E.

1974 Der Anitta-Text. Series: Studien zu den Boğazköy-Texten 18. Wiesbaden: Otto Harrassowitz.

1988a Das Hurritische: Eine altorientalische Sprache in neuem Licht. Series: Akademie der Wissenschaften und der Literatur. Abhandlungen der Geistes- und Sozialwissenschaftlichen Klasse. Jahrgang 1988, Number 3. Stuttgart: Franz Steiner.

1988b Zur Grammatik des Hurritischen auf der grundlage der hurritischhethitischen Bilingue aus der Boğazköy-grabungskampagne 1983. Pp. 95-115 in Xenia, Hurriter und Hurritisch. Konstanzer Althistorische Vorträge und Forschungen, heft 21, edited by V. Haas. Konstanz: Universitätsverlag Konstanz.

1988c Varia Hurritica. Sprachliche Beobachtungen an der hurritischhethitischen Bilingue aus Hattuša. Pp. 235-54 in Documentum Asiae Minoris Antiquae: Festschrift für Heinrich Otten zum 75. Geburtstag.

1988d Zum hurritischen 'Essiv' in der hurritische-hethitischen Bilingue aus Hattuša. Hethitica IX: 157-70

Neve, P.

1982 Büyükkale. Die Bauwerke. Berlin: Gebr. Mann.

1985 Die Ausgrabungen in Boğazköy-Hattuša 1984. Pp. 323-52 in Archäologischer Anzeiger. Berlin: Walter de Gruyter.

1987a Die Ausgrabungen in Boğazköy-Hattuša 1986. Pp. 381-410 in Archä- ologischer Anzeiger. Berlin: Walter de Gruyter.

1987b Hattuscha, Haupt- und Kultstadt der Hethiter-Ergebnisse der Ausgrabungen in der Oberstadt. Hethitica VIII: 297-318.

Oppenheim, H. L.

1956 The Interpretation of Dreams in the Ancient Near East. Philadelphia:

Otten, $\mathrm{H}$ American Philosophical Society.

1955 Bibliotheken im Alten Orient. Das Altertum 1: 67-81.

1956 Hethitische Schreiber in ihren Briefen Mitteilungen des Instituts für Orientforschung 4: 179-89.

1958 Die erste Tafel des hethitischen Gilgamesch-Epos. Istanbul Mitteilungen 8: 93-125.

1961 Das Hethiterreich. In Kulturgeschichte des Alten Orients, edited by H. Schmökel. Stuttgart: A. Kröhner.

1963 Aitiologische Erzählung von der Überquerung des Taurus. Zeitschrift für Assyriologie, Neue Folge 21: 156-68.

1964 Schrift, Sprache und Literatur der Hethiter. Pp. 11-22 in Nevere Hethi-

terforschung, edited by G. Walser. Series: Historia, Einzelschriften 7. Wiesbaden: Franz Steiner.

1973 Eine althethitische Erzählung um die Stadt Zalpa. Series: Studien zu den Boğazköy-Texten 17. Wiesbaden: Otto Harrassowitz.

1981 Die Apologie Hattušilis III: Das Bild der Überlieferung. Series: Studien zu den Boğazköy-Texten 24. Wiesbaden: Otto Harrassowitz.

1984 Blick in die altorientalische Geisteswelt: Neufund einer hethitischen Tempelbibliothek. Jahrbuch der Akademie der Wissenschaften in Göttingen: 50-60.

1986 Archive und Bibliotheken in Hattuša Pp. 184-90 in Cuneiform Archives and Libraries, edited by K. R. Veenhof. Leiden: Nederlands HistorischArchaeologisch Instituut te Istanbul.

1987 Das hethitische Königshaus im 15. Jahrhundert v. Chr. Anzeiger der phil.hist. Klasse der Österreichischen Akademie der Wissenschaften 123: 21-34.

1988 Die Bronzetafel aus Boğazköy. Wiesbaden: Otto Harrassowitz.

1989 Die 1986 in Boğazköy gefundene Bronzetafel Zwei Vorträge. 1. Ein hethitischen Staatsvertrag des 13 Jahrhundert v. Chr. Innsbrucker Beiträge zur Sprachwissenschaft. Vorträge und Kleine Schriften 42 : 7-20.

Özgüç, N.

1986 Seals of the Old Assyrian Colony
Period and Some Observations on the Seal Impressions. Pp. 48-53 in Ancient Anatolia: Aspects of Change and Cultural Development: Essays in Honor of Machteld I. Mellink, edited by J. V. Canby and others. Madison, WI: University of Wisconsin Press.

Özgüç, T.

1978 Excavations at Maşat Höyük and Investigations in its Vicinity. Series: Türk Tarih Kurumu Yayinlarindan, Series V, Number 38. Ankara.

1986 New Observations on the Relationship of Kültepe with Southeast Anatolia and North Syria During the Third Millennium B.C. Pp. 31-47 in Ancient Anatolia: Aspects of Change and Cultural Development: Essays in Honor of Machteld J. Mellink, edited by J. V. Canby and others. Madison, WI: University of Wisconsin Press.

Salvini, M.

1977 Sui testi mitologici in lingua hurrica. Studi Micenei ed Egeo-Anatolici 18: 73-91.

Schirmer, W.

1969 Die Bebauung am unteren Büyükkale-Nordwesthang in Boğazköy. Berlin: Gebr. Mann

Schuler, E. von

1987 Literatur bei den Hethitern. Reallexikon der Assyriologie und vorderasiatischen Archäologie 7: 66-75.

Seters, J. van

1983 Hittite Historiography. Pp. 100-26 in In Search of History. New Haven, CT: Yale University Press.

Siegelová, J.

1971 Appu-Märchen und HedammuMythus. Series: Studien zu den Boğazköy-Texten 14. Wiesbaden: Otto Harrassowitz.

Soysal, O.

1987 KUB XXXI 4 + KBo III 41 und 40 (Die Puhanu-Chronik). Zum Thronstreit Hattusilis. Hethitica VII: 173-253.

Steiner, G.

1984 Struktur und Bedeutung des sog. Anitta-Textes. Oriens antiquus 23 53-73.

Sturtevant E. H., and Bechtel, B.

1935 A Hittite Chrestomathy. Philadelphia: Linguistic Society of America, University of Pennsylvania.

Ünal, A.

1974 Hattušili III. Series: Texte der Hethiter 3. Heidelberg: Carl Winter.

1977 Naturkatastrophen in Anatolien im 2. Jahrtausend v. Chr. Belleten 163: 447-72.

1978 Ein Wahrsagetext über die Intrigen am hethitischen Hof. Series: Texte 
der Hethiter 6. Heidelberg: Carl Winter.

1980 Kešši. Reallexikon der Assyriologie und vorderasiatischen Archäologie 5: 578 .

1983a Untersuchungen zur Terminologie der hethitischen Kriegsführung I: "Verbrennen, in Brand stecken" als Kriegstechnik. Orientalia 52: 164-80.

1983b Kuššara. Reallexikon der Assyriologie und vorderasiatischen Archäologie 5: 379-82.

1985 Das Motiv der Kindesaussetzung in den altanatolischen Literaturen. Pp. 129-36 in Keilschriftliche Literaturen: Ausgewählte Vorträge der XXXII. Rencontre Assyriologique Internationale, edited by $\mathrm{H}$. Hecker and W. Sommerfeld. Berlin: Dietrich Reimer

1988 The Role of Magic in the Ancient Anatolian Religions According to the Cuneiform Texts from BoğazköyHattuša. Pp. 52-85 in Essays on Anatolian Studies in the Second Millennium B.C., edited by Prince T. Mikasa. Wiesbaden: Otto Harrassowitz.

de Vries, B.

1967 The Style of Hittite Epic and Mythology. Ph.D. dissertation. Waltham, MA: Brandeis University. (Ann Arbor, MI: University Microfilms)

Weidner, E. F.

1923 Politische Dokumente aus Kleinasien: die Staatsverträge in akkadischer Sprache aus dem Archiv von Boghazköi. Leipzig: J. C. Hinrichs.

Werner, R.

1967 Hethitische Gerichtsprotokolle. Series: Studien zu den BoğazköyTexten 4. Wiesbaden: Otto Harrassowitz.

Wolf, H. H.

1967 The Apology of Hattusili Compared with Other Political Self-Justifications of the Ancient Near East. Ph.D. dissertation. (Ann Arbor, MI: University Microfilms|

Xella, P.

1978 Remarques comparatives sur le "roman de Kessi." Revue Hittite et Asianique 36: 215-24.
Glossary

Acemhöyük. Large tell near Aksaray in central Turkey, probably to be identified with ancient Purušhanda. During the nineteenth century B.C.E. the town was the site of an Assyrian trading colony, or kārum. Since 1962 it has been excavated by a Turkish team under the direction of Nimet Özgüç.

Akkadian. A Semitic language spoken in Mesopotamia from the third through the first millennium B.C.E.; also, the people who spoke the language.

Alaca Höyük. A site located 15 miles north of modern-day Boğazköy that is famous for its royal tombs dating to the third millennium B.C.E. in the Early Anatolian period, which roughly corresponds to the Early Bronze Age. Metal artifacts found at the site-in particular, mirrors, swords, and daggers - tend to be of high quality, and several finds have parallels in Aegean and Soviet sites. The royal tombs and grave goods are often used to connect an Indo-European origin for the Hittites. The site also has several significant monumental sculptures that date to the Hittite Empire.

Anitta Text (CTH 1). An Old Hittite text in which Anitta, king of Kuššara, describes his conquest of several Anatolian cities and the subsequent building of his newly created empire. Written in Hittite, the text was discovered at the Hittite capital of Hattuša, one of the cities Anitta claims to have conquered. Because it describes events that took place immediately prior to the formation of the Hittite state, the Anitta Text is one of the most important historical sources for the study of pre-Hittite and very early Hittite history.

Annals of Hattušili I (CTH 4). Text from the Hattuša archives that describes some of the campaigns of Hattušili I, the first Hittite king to build a substantial empire and leave extensive records of his reign. The text exists in both Akkadian and Hittite versions.

Anum-Hirbe. A prince of the city of Mama during the Colony Age when Anatolia was the site of numerous Assyrian trading colonies. Anum-Hirbe was a contemporary of Waršama, a prince of Kaneš. Both are known from the letter written by Anum-Hirbe to Waršama that was discovered in the excavation of the palace at Kaneš. Written in Old Assyrian, the letter advocates the establishment of regular diplomatic relations between the two princes.

Arinna. (see Sun-Goddess of Arinna) Boğazköy. (see Hattuša)

Çatal Höyük. A Neolithic site dating to the seventh millennium B.C.E. Situated in the Konya plain, southeast of the modern city of Konya, Çatal Höyük grew to a considerable size and was characterized by several significant cultural innovations. Its inhabitants apparently developed an irrigation system and hybrid grains that produced high yields. They were involved in, and may have controlled, widespread trade /obsidian from central Anatolia has been found in excavations as far away as Jerichol, and they had a well-developed chipped stone industry. Pottery and artistic remains also attest to the highly developed culture of this significant site.

Central Place Theory. A geographic model using adjacent hexagons to explain the distribution of cities and their surrounding villages. The central place is defined as the focus of a series of hexagons that contain towns, villages, and hamlets. A service-oriented reciprocal relationship exists between the central place and its satellite settlements.

Chthonic. From the Greek chthôn ("earth"), a term referring to deities and religious concepts and practices concerned with the soil, fertility, the underworld, death, and the afterlife.

Colony Age. A period of Anatolian history that lasted for about two centuries (from around 1925 to 1725 B.C.E. according to the middle chronology or 1925 to 1650 B.C.E. according to the low chronology) and was marked by the establishment of Assyrian trading colonies (Akkadian kārum and wabartum) in central Anatolia. Tin, which was used in the production of bronze, and textiles were brought to Anatolia from Assyria in exchange for gold, silver, and semiprecious stones. Among the sites that functioned as trading outposts were Hattuša, Kaneš, and Karahöyük.

Extispicy. Divination by "reading" the entrails of sacrificial animals, a common ritual practiced in ancient Mesopotamia and Anatolia. Perhaps the best known collection of omen texts is the Akkadian šmma izbum series, which lists anomalies in entrails and aborted or miscarried animal fetuses and their appropriate interpretation. 